Південноукраїнський національний педагогічний університет

імені К.Д. Ушинського (м. Одеса) e-mail:veraok888@ukr.net

ORCID: 0000-0003-0661-4313

\title{
МОДЕЛЬ ВІРТУАЛЬНОї ЛЮДИНИ ДОБИ ПОСТМОДЕРНУ
}

Резюме. Стаття присвячена розгляду антропологічної моделі людини доби Постмодерну, зокрема основний погляд акиентовано на віртуальну людину як новий тип особистості. Віртуальна людина є ознакою сучасних соиіокультурних трансформацій, особливо в сфері інформаційно-комунікативних технологій, тобто віртуалізації суспільства. Причому, дана модель має свої риси, проективний характер, оскільки має спрямованість на майбутнє суспільства, в якості перехідної ланки до майбутньої моделі людини.

Ключові слова: модель, віртуальна людина, віртуальна особистість, віртуалізація, Постмодерн.

Окорокова В.В., Южноукраинский национальный педагогический университет имени К.Д. Ушинского (2. Oдесса), e-mail: veraok888@ukr.net,.ORCID: 0000-0003-0661-4313

Модель виртуального человека времени Постмодерна.

Резюме. Статья посвящена рассмотрению антропологической модели человека времени Постмодерна, в частности основной взгляд акиентирован на виртуального человека как новый тип личности. Виртуальный человек является признаком современных сочиокультурных трансформаций, особенно в сфере информационно-коммуникативных технологий, то есть виртуализации общества. Причем, данная модель имеет свои черты, проективный характер, поскольку имеет направленность на будущеее общества, в качестве переходного звена к будущей модели человека.

Ключевые слова: модель, виртуальный человек, виртуальная личность, виртуализация, Постмодерн.

Okorokova V.V., South Ukrainian Pedagogical University named after K.D. Ushynsky, (Odessa), e-mail:veraok888@ukr.net, ORCID:0000-0003-0661-4313

\section{Model of virtual man of twenty-four hours Post-modern.}

Abstract. A problem of virtual man is one of most actual in modern science. The specific of her is a that circumstance, that she has interdisciplinary character, in particular she can be examined in a sphere to philosophy, culturology, history, and sociology. Speaking about actuality of the outlined subjects, it follows Tom to take into account those sociocultural transformations that take place in modern society on ontological and axiology levels, in fact catch man as to personality through the prism of consciousness of that it takes place changes in a world view, attitude toward a social environment, to scientific and technical.

The scientific novelty of this research consists in that in modern philosophy, in a counterbalance to considerable actuality of this theme, there is a small amount of the works devoted directly to the analysis of virtual man. Moreover, it follows to take into account that circumstance, that among the modern researchers of this problem there is a discussion, as exactly it is not known as a virtual man has lines and properties, or it is possible to name her virtual person and in what difference between these by concepts and them difference from a man and personality. 
Taking into account the foundations of actuality and scientific novelty indicated higher, an author pays attention to exactly those submarine stones, that resulted in the origin of this concept (digital revolution, that with each sometimes all anymore captivates spare time of modern man, that she conducts in virtual reality, there is the Internet in networks). Marked, that the virtualization of society assisted the $\ddot{i}$ virtualization of man as personality implicitly. Immersion in the virtual world, allows to the man to realize those elements of the real life, that she can not carry out in social reality. Together with it and consciousness of man begins to perceive the world through the prism of simulacra (characters, signs) that is generated by computer technologies. To Tom, an author comes to the conclusion, that a virtual man it a transitional link to the man of the future in the world of swift development and perfection of virtual technologies.

Keywords: model, virtual person, virtual personality, virtualization, Postmodern.

Самоконструювання, безтілесність і множинність, хаотичність, критика об'єктивного пізнання соціальної реальності як характерні риси постмодерністського соціуму вказують на основні засади все більш зростаючої актуальності мережевої комунікації, віртуальної реальності. Як зазначають деякі дослідники з приводу сучасних трансформаційних процесів в суспільстві, сама категорія «світ» зазнала змін [4, с. 42]. Для сучасної людини «світ» складається ніби з двох «світів», в яких відбувається їі життя — це світ реальний і світ віртуальний. Причому останній (інтернет-світ) $€$ не тільки тим особливим світом, де можна отримати будь-якого роду інформацію, але і середовищем спілкування і середовищем життя, миром, де відбувається безліч тих же процесів, що і в реальному соціумі.

Інакше кажучи поява принципово нового типу інформаційного суспільства та розвиток мережевих комунікацій різко змінюють характер соціалізації i, отже, формування особистісної ідентичності. Соціалізація в сучасному суспільстві знайшла нове значення, розглядаючись як інформаційна соціалізація. Як зазначають В.В. Афанасьєва, Є.О. Горний, С.I. Черних, Г.В. Прохоров-Малясов процеси віртуалізації суспільства (як моделювання) сприяли і формуванню моделі віртуальної особистості. Зокрема Г.В. Прохоров-Малясов звертає увагу на те, що в ситуації, що склалася, виняткової актуальності набула проблема антропної ідентичності, яка $є$ вираженням унікальної особливості людини, що складається в тому, що тільки для людини її власне існування є проблемою [6]. Сучасне людство не помітило, як переступило цю грань. Проблема ідентичності має в фокусі питання про самоідентифікацію людини, тобто питання про те, чи може людина сама обгрунтувати статус свого буття, зрозуміти, що є людиною, або повинна «отримати», знайти десь поза межами свого буття себе як людину. Відтак, окреслені аспекти даної проблематики обумовлюють мету даного дослідження - розглянути модель віртуальної людини в сучасному суспільстві, визначити іï риси.

Сучасний об'єктивний інформаційно-технічний світ ставить питання: чи здатна людина в такому світі наблизитися до «досягненню мети свого призначення», чи стане людина завдяки науково-технічній діяльності більш гуманною? Наявним $є$ те, що завдяки технічній діяльності людини, формуються образи сучасного світу. Нова реальність, яка спирається в своєму становленні на передові інформаційно-комп'ютерні технології, явила людині ідею віртуальної реальності.

Інакше кажучи проблема соціальної ідентичності людини в епоху віртуалізації суспільства явно вказує на існування нової соціально-культурної спільності людей, об'єднаних прагненням значну частину свого життя проводити у віртуальному світі, де успішно задовольняються їх основні культурні та соціальні потреби. І в цьому сенсі одним з найбільш значущих підсумків віртуалізації всіх сфер життя слід визнати виникнення «Homo virtualis», людини віртуальної, яка орієнтована на віртуальність, що володіє надмірно віртуалізованою 
свідомістю і є творцем, носієм і споживачем віртуальних феноменів. Саме в віртуальному просторі віртуальна людина працює, вчиться, відпочиває, спілкується, споживає інформацію і задоволення, саме для «Ноmo virtualis» і за допомогою «Ноmo virtualis» виникають i існують всі нові і нові віртуальні феномени, цілі віртуальні світи.

В першу чергу, поява яскраво вираженої людини віртуальної пов'язана 3 повсюдним поширенням комп'ютерних мереж, враховуючи при цьому, що процеси віртуалізації людської свідомості визначаються і діяльністю засобів масової інформації, в тому числі, телебаченням, радіо, преси, індустрією масової пропаганди, віртуалізацією комунікацій, творчості, творінням нових міфів і т. п. Люди віртуальні набувають специфічні психологічні характеристики, а поява «людини віртуальної» ставить перед сучасною психологією, зокрема віртуальною психологією як нового напрямку в області психології, безліч проблем [1, c. 60].

Сьогодні вже слід розрізняти «поза-віртуальну» і «віртуальну» людські особистості. Нова віртуальна особистість, яка формується, розкривається через самосвідомість і самоспіввіднесенність всередині самої ж віртуальної реальності. Для цієї віртуальної особистості образи віртуального світу не є недовтіленими або алегоричними, вони цілком реальні, бо існують 3 нею в одному просторі. $\mathrm{y}$ «Homo virtualis» особливі, умовні антропні характеристики, нетривіальні ідентифікація і самоідентифікація, оскільки у просторі віртуальної реальності в процесах віртуального спілкування будь-яка людина може придбати бажані зовнішність, вік, стать, національність і т. п.

Взагалі то вираження «віртуальна особистість» в широкому сенсі, як і їі англомовний аналог «virtual identity», багатозначне і має цілий ряд синонімів, значення яких перетинаються лише частково. Основні значення терміна віртуальна особистість такі:

1) ідентифікатор для входу в комп'ютерну систему (login, user name);
2) прізвисько або псевдонім, що використовуються для ідентифікації користувача в електронному середовищі (user name, nickname);

3) абстрактна репрезентація особистості, яка використовується для її цивільної, правової та іншої соціальної ідентифікації (номер паспорта, особистий код, відбитки пальців, DNA);

4) комп'ютерна програма, що моделює розумну поведінку (robot, bot);

5) те саме, але в поєднанні з тілом (android, cyborg);

6) вигадана особа, яка створена людиною або групою людей, що породжує семіотичні артефакти і / або описувана ззовні (virtual character, virtual persona);

7) будь-яка особа, як вона сприймається або моделюється ким-небудь; іншими словами, образи чи іпостасі особистості як щось відмінне від іiї сутності (наприклад, «я» (ego) в його протиставленні «самості» (self)) [2].

Причому, найчастіше вчені оперують саме шостим визначенням даного поняття, пояснюючи це тим, що в такому розумінні віртуальна особистість характеризується зняттям опозиції між істиною і брехнею, фактичностью і фіктивністю, реальністю і нереальністю, матеріальністю і ідеальністю, що зближує іiї 3 твором мистецтва.

Найважливішою особливістю віртуальної особистості $\epsilon$ наявність яскраво виражених залежностей. Існує думка, що творіння віртуальної реальності створює основу для максимального збільшення свободи індивідуумів, свободи творчості і т. п. Однак теза про зростання індивідуальних свобод для «Homo virtualis» сумнівна і нівелюється залежністю свідомості і способу життя людини, орієнтованого на віртуальність, від функціонування комп'ютерних мереж і своєї нової, віртуальної особистості. Негативний вплив віртуальної реальності на психіку і здоров'я людей, наприклад інтернетоманія і телеманія, широко обговорюється в психологічній і медичній літературі. Виходячи $з$ цих міркувань, В. В. Афанасьєва вважає, що суттєвою характеристикою віртуальної особистості $€$ саме $\dddot{\text { ii }}$ 
несвобода, залежність від віртуальних просторів, в яких вона формується і перебуває [1, c. 61].

Теперішня людина віртуальна — це людина колективна. Психологи і соціологи вважають, що прагнення потрапити в мережу закладене в людині на генетичному рівні. Сьогодні вже встановлено, що мережеві соціальні структури пожвавлюють генетичну пам'ять про первісне суспільство, про відсутність соціальної та майнової ієрархії, привілеїв, поділу на «керівників» $\mathrm{i}$ «підлеглих», про можливість існування в житті співтовариства тільки часткового або тимчасового лідерства. 3 огляду на це, інтернет можна розглядати як модель, яка воскрешає деякі риси первісного минулого, адже все вищесказане точно відповідає мережевій етиці та відомої на сьогоднішній день структурі інтернету. Бурхливе зростання мережі і створення «електронних общин» проявляються як реакція на ізоляцію суб'єкта сучасного соціуму. інтернет компенсує процес атомізації суспільства, включає генетичну пам'ять про вихідний соціум, поміщає людину в гранично демократичний віртуальний колектив.

Вивчаючи онтологію віртуальної особистості С. I. Черних пропонує використовувати концепцію символічного інтеракціонізму, представники якої (Дж. Г. Мід, У. А. Томас, Г. Блумер, Ч. Х. Кулі і ін.) сформулювали на основі розрізнення пізнання речей і особистостей в рамках соціально-філософського дискурсу мови і культури в їх сигніфікативній функції ряд оригінальних ідей для розуміння взаємодії «я» і «Іншого» [9, с. 75]. Мета концепту - не лише усвідомлення нашого ставлення до «Іншого» як до ідеї особистості, а до того, чим «я» $є$ насправді. «Если конституирущие реальность интепретации (знание) представляют собой символическое взаимодействие (результат) между двумя «я», то первое «я» как видение себя глазами других вызывает у меня ту же реакцию, что и у других. Если второе «я» (мое видение - самого себя) является источником креативности, то первое «я» задает позицию рефлексии по отношению к самому себе». Виникає ланцюг образів символічного характеру, продовжує вчений, що дозволяє «я» інтерпретувати самого себе в будь-якому складному акті комунікації. Але тоді «визначення ситуації як дійсної робить ситуацію дійсною»; «Дії з символами передують практично-перетворювальним діям»; «Соціальне життя, в кінцевому підсумку, є продукт символічних інтерпретацій і ії дослідження має бути орієнтоване на осмислення символічних процесів діючих суб'єктів і підтримуючих цю дію структур».

Розвиваючи подібні ідеї, вчений звертає увагу на те, що символ для таких комунікативних взаємодій цілком уявний як «ідея, образ або об'єкт, який має власний зміст і одночасно представляє в узагальненій, нерозгорнутій формі деякий інший зміст». «Символ стоїть між (чистим) знаком, у якого власне утримання $\epsilon$ мізерним, і моделлю, що має пряму схожість 3 модельований об'єктом, що дозволяє моделі захищати останній в процесі дослідження». Таке розуміння символу постулює одне з вихідних підстав символічного інтеракціонізму: у взаємодіях людей пріоритетним в конституюванні реальності $\epsilon$ символічний тип взаємодії, тобто в соціальній взаємодії ми маємо справу з їх символами. «Символ в символічному інтеракціонізму є модуль дії, а не засоби передачі інформації» [9, с. 76].

Через це в сучасній філософській літератуpi, продовжує С. І. Черних, ведуться інтенсивні дискусії про те, чи можна вважати віртуальну особистість особистістю [9, с. 76]. Якщо в традиційній літературі особистість визначається єдністю тілесного і духовного, то віртуальний світ передбачає примусову відсутність тілесність. Виникаюча при цьому поліонтичність буття особистості породжує абсолютно нову тенденцію іiї розвитку: можливість створення необмеженої кількості взаємодій як тиражування «себе іншого». «Віртуальна особистість відрізняється від реальної тим, що вона не має матеріального тіла і складається виключно із знаків і дій (а також, подібно до реальної особистості з образів, думок і почуттів, які вона породжує в психіці спостережень). Віртуальна особистість є об'єкт, 
якому приписують якості суб'єкта, але статус існування якого не визначений. «Віртуальне» тут позначає нейтралізацію між «реальним» і «нереальним», — пише С. О. Горний [3, с. 80].

Розглядаючи історію появи поняття «віртуальна особистість» слід зазначити, що воно з'явилося раніше інтернету. Як відмічає Б. Крігер, цим терміном позначали псевдоніми, акторські амплуа, ролі, за якими судили про особу актора. Тобто «віртуальний» тут означає «фіктивний», «уявний», «той що мариться». Це словосполучення вживається також в тому випадку, якщо обліковий запис блогу або веб-форуму жодним чином не може бути асоційовано з реальною особистістю [5]. Цією категорією часто означають «віртуальну маску» («личину»), підкреслюють, що в «соціальних мережах» людина найчастіше грає i «дуркує» [7].

Вивчаючи філософію віртуальної особистості І. М. Пупишева говорить про мовну природу «віртуальної особистості», їі «соціальні зв'язки і відносини» мають на увазі мовне i здебільшого письмове спілкування [7]. Тобто в мережі перед нами «мовна особистість», причому найчастіше «постмодерністського» спрямування - в прагненні зафіксувати, перетворити в «текст» кожну значущу подію, а також зацитувати, «послатися». У традиційному розумінні «мовна особистість» складається 3 лінгвістичних здібностей творити мовні тексти, тут же включається здатність вдало цитувати і комбінувати. Соціальна ідентичність в цьому аспекті вже пов'язана не тільки з «тим, що пишу», а й 3 «тим, що читаю» (або «кого читаю»). Категорія «кого читати» теж отримує нове значення: «читати» - значить регулярно дізнаватися про події «віртуального» життя людини - кого «зафрендити» (або «розфрендити»), який встановив «статус», яку зробив «замітку», де залишив коментар і т. п. Таким чином, «підглядання» один за одним стає правилом соціальної гри. Один фіксує і веде протокол факти і явища (роблячи це «напоказ») в надії, що це перетворить їх спочатку в «знакові», а потім 3 «знакових» в значимі події; а інший, «проходячи повз», схвалює і підтримує ïx — «плюсиком», коментарем, «оцінкою» або не зазначає ніяк. У цій «грі» виставляння напоказ - норма, а не «непристойність», такою ж нормою стає і «підглядання».

Людина, яка стала активним «користувачем», починає «писати» своє життя відповідно до законів організації художнього тексту: веде «щоденникові» записи, залишає коментарі, робить «нотатки», викладає «фотозвіти». Життя людини втратило (розчинило) в соціальних мережах деяку частку сакральності і приватності. Отримавши можливість регулярно бути «on-line», людина стала більш публічною в своїх проявах, стала часом замислюватися не просто над подією, а над іiї «художньої» подачею в мережу (фотографування, відео), тобто можна говорити про формування нового «соціального рефлексу».

На думку I. М. Пупишевої в створенні віртуального «я» людина змогла наблизитися до мистецтва. Тенденція до «саморепрезентації» відповідно до законів літературної творчості породжує появу «особистостей», крім як в інтернеті, ніде більше не представлених. «Віртуальний» спосіб життя виявляється досить правдоподібним і «життєздатним» сам по собі. «Віртуальна особистість» - сучасний аналог «художнього образу», що представляє йому альтернативу в технічному насамперед плані. Вона складається із сукупності «персональних сторінок», «щоденникових записів», фотозвітів, вподобаних відео- і аудіозаписів, коментарів на чужі фото, відео і замітки [7].

Окреслене вище дозволяє говорити про те, що «віртуальна особистість» (віртуальне «я») міцно зростається 3 «реальною», визначаючи iï поведінку і коло спілкування (а тому і соціальні відносини) в звичайному житті. Постмодерністське прагнення до текстуального протоколювання, що характеризує спочатку лише літературну творчість, стало характеристикою самого життя - в її «віртуальному» мовному прояві. Все це поступово призводить до формування людини публічної і націленої разом 3 тим на повсюдну «приватизацію» подій, явищ, фактів. «Особистість» у віртуальному середовищі і складається 3 цієї «при- 
ватизації», відкритої для обговорення, що, в свою чергу, проникає і в область літератури як самостійний жанр.

Окремий інтерес викликає думка, панівна серед вчених, про те, що віртуальна особистість не є чимось винятковим і новим в історії культури. Її основні атрибути, які свідчать разом з тим про глибинні ментальні домінанти європейської культури, вже не раз обігравалися як в філософії, так і в літературі, а нині вони отримали лише ще одну можливість для самооб'ективації - на новому технологічному рівні.

Виходячи з цих положень, О. В. Хитров виділяє наступні особливості моделі віртуальної особистості, порівнюючи іiі з іншими особистісними моделями новоєвропейської культури:

Самотворення або самоконструювання, які часто кваліфікуються як унікальні ознаки саме мережевої особистості. Онлайнові щоденники служать, мабуть, найкращою ілюстрацією цього принципу. Жива, постійно оновлювана, динамічна особистісна історія народжується у нас на очах. Самоопис, що $\epsilon$ семіотичною самогенерацією особистості, прямо або побічно присутній в будь-якому мережевому щоденнику.

У зв'язку з цим варто зазначити, що дана особистісна модель вже була досить детально розроблена в історії європейської культури. Йдеться про модель self-made man, базис якої можна побачити в двох культурних програмах раннього Нового часу — південному (художньому) і в північному (релігійному) Відродженні. Титанизм Італії, що стихійно самостверджується, і протестантський дух північної Європи об’єднувала ідея індивідуальної відповідальності за свою особистість, усвідомлення іiі пластичності, можливість поглянути на неї як на проект. Варіаціями на цю тему стала суб'ектоцентрична гносеологія Нового часу.

- Можливість існування особистості без тіла, закріплення за тілом ролі такого собі атавізму в справжньому житті людської істоти неодноразово програвалося в культурних традиціях. Традиційний погляд на суб'єкта в філософії Нового часу може служити найпереконливішим прикладом. Суб'єкт новоєвропейської культури діяв в іпостасі мислячого Я, безтілесного інтелектуального згустку. Відсутність тілесності в віртуальному просторі не вимагає спеціальних доказів. У блогосфері замінниками тілесності служать, перш за все, різні візуальні практики: викладання власних фотографій, вибір так званих «аватарів» або «юзерпіків».

- Ідея множинності особистості також має багату традицію. У новоєвропейській думці першим про ілюзії постійного, єдиного, безперервно існуючого, простого і тотожного собі Я заговорив Д. Юм. Він знаходився в явній опозиції до трактування особистості як субстанції і константи, запропонованої раніше Декартом. Модель децентрированої, множинної, плинної та несубстанціональної особистості обігрувалася і в літературних практиках. У блогосфері ідея множинності особистості реалізується в створенні віртуальних двійників, або «віртуалів», втілення яких нерідко зазнає свого роду відчуження i дистанціюється від авторської свідомості, починає змушувати автора слідувати своїй власній логіці [8, с. 71-72].

Таким чином, «Homo virtualis» орієнтований лише на віртуальність, як світ, в якому проходить його діяльність. При такому розумінні людина віртуальна $\epsilon$ вже випробуваною моделлю, учасниками якої ми і є. Створюючи віртуальні світи, удосконалюючи їх, ми на свідомому рівні все більше занурюємося в штучну реальність, все частіше пориваючи 3 соціальною дійсністю. Віртуальна людина володіє надмірно віртуалізованою свідомістю, є творцем, носієм і споживачем віртуальних феноменів. Віртуальна реальність їй замінює реальність як таку.

У просторі віртуальної реальності будь-яка людина може придбати бажані атрибути (вік, стать, професію, нові психологічні і фізиологічні риси т. п.). Віртуальна людина $є$ початковою сходинкою у формуванні сучасною людиною образу нової людини майбутнього, 
«Філософія та політологія в контексті сучасної культури», 2018, Т.10. №1-2 (22)

причому глобалізаційного рівня. Особливістю даного процесу є те, що він сприймається лю-

диною на підсвідомому рівні, як відповідь на сучасні зміни у світогляді.

\section{Бібліографічні посилання}

1. Афанасьева В.В. Ноmo Virtualis: психологические характеристики. Известия Саратовского университета. 2010. Т. 10. С. 59-64.

2. Горный Е.А. Виртуальная личность как жанр творчества. URL: https:/prochtenie.org/ passage/24481

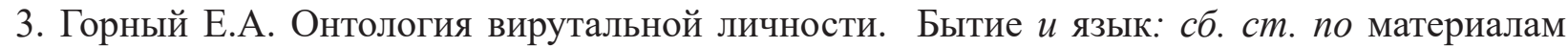
межд. конф. Новосибирск, 2004. С. 78-88.

4. Крамаренко Н.С. Виртуальный мир как новое пространство самоосуществления человека. Вестник Адыгейского государственного университета. 2013. Вып. 4. С. 42-48.

5. Кригер Б. Виртуальная личность: мифы и реальность. URL: http://mirbudushego.ru/ram/ kriger/ch3.htm

6. Прохоров-Малясов Г.В. Виртуальная реальность: в поисках антропной идентичности. Материалы межвузовской конференции. Казань, 2000. С. 35-38.

7. Пупышева И.Н. На подступах к «Виртуальной» антропологи. URL: https://cyberleninka.ru

8. Хитров А. Блог как феномен культуры. Журнал социологии $u$ социальной антропологии. 2007. № 1. Т. 10. С. 66-76.

9. Черных С.И. Феномен вирутальной личности в сременной философии. Философия образования. 2011. № 3. С. 72-78.

\section{References}

1. Afanas'eva V.V. (2010). Homo Virtualis: psihologicheskie harakteristiki. [Homo Virtualis : psychological descriptions]. Izvestiya Saratovskogo universiteta. T. 10. S. 59-64.

2. Gornyj E.A. Virtual'naya lichnost' kak zhanr tvorchestva. [Virtual personality as genre of work]. URL: https://prochtenie.org/passage/24481

3. Gornyj E.A. (2004). Ontologiya virutal'noj lichnosti. [Ontology of virtual personality]. Bytie $i$ yazyk: sb. st. po materialam mezhd. konf. Novosibirsk. S. 78-88.

4. Kramarenko N.S. (2013). Virtual'nyj mir kak novoe prostranstvo samoosushchestvleniya cheloveka. [Virtual world as new space of realizations of man]. Vestnik Adygejskogo gosudarstvennogo universiteta. Vyp. 4. S. 42-48.

5. Kriger B. Virtual'naya lichnost': mify i real'nost'. [Virtual personality: myths and reality]. URL: http://mirbudushego.ru/ram/kriger/ch3.htm

6. Prohorov-Malyasov G.V. (2000). Virtual'naya real'nost': v poiskah antropnoj identichnosti. [Virtual reality: in search of anthropological identity]. Materialy mezhvuzovskoj konferencii. Kazan'. S. 35-38.

7. Pupysheva I.N. Na podstupah k «Virtual'noj» antropologi. [On approaches to «Virtual» anthropologists]. URL: https://cyberleninka.ru

8. Hitrov A. (2007). Blog kak fenomen kul'tury. [Blog as phenomenon of culture]. ZHurnal sociologii i social'noj antropologii. № 1. T. 10. S. 66-76.

9. Chernyh S.I. (2011). Fenomen virutal'noj lichnosti v sovremennoj filosofii. [The phenomenon of virtual personality is in modern philosophy]. Filosofiya obrazovaniya. № 3. S. 72-78. 